Atmos. Chem. Phys., 10, 3891-3899, 2010

www.atmos-chem-phys.net/10/3891/2010/

(C) Author(s) 2010. This work is distributed under

the Creative Commons Attribution 3.0 License.

\title{
Volcanic ash as fertiliser for the surface ocean
}

\author{
B. Langmann ${ }^{1}$, K. Zakšek ${ }^{1}$, M. Hort ${ }^{1}$, and S. Duggen ${ }^{2}$ \\ ${ }^{1}$ Institute of Geophysics, University of Hamburg, KlimaCampus, Hamburg, Germany \\ ${ }^{2}$ Leibniz Institute of Marine Sciences, IFM-GEOMAR, Kiel, Germany
}

Received: 11 December 2009 - Published in Atmos. Chem. Phys. Discuss.: 14 January 2010

Revised: 8 April 2010 - Accepted: 25 April 2010 - Published: 27 April 2010

\begin{abstract}
Iron is a key limiting micro-nutrient for marine primary productivity. It can be supplied to the ocean by atmospheric dust deposition. Volcanic ash deposition into the ocean represents another external and so far largely neglected source of iron. This study demonstrates strong evidence for natural fertilisation in the iron-limited oceanic area of the NE Pacific, induced by volcanic ash from the eruption of Kasatochi volcano in August 2008. Atmospheric and oceanic conditions were favourable to generate a massive phytoplankton bloom in the NE Pacific Ocean which for the first time strongly suggests a connection between oceanic iron-fertilisation and volcanic ash supply.
\end{abstract}

\section{Introduction}

Volcanic ash represents a so far largely neglected component of the surface ocean biogeochemical iron-cycle and marine primary productivity (MPP) which can be limited by the availability of macro-nutrients like nitrate and phosphate. In so-called "High-Nutrient-Low-Chlorophyll" (HNLC) areas (the northern and equatorial Pacific and the Southern Ocean, which make up about $20 \%$ of the total ocean area) macro-nutrient concentrations are high, but iron $(\mathrm{Fe})$ is the key biologically limiting micro-nutrient for primary productivity (Martin and Fitzwater, 1988). Three major sources for iron supply into the ocean have been considered so far: upwelling of deep ocean water (Castro and Huber, 2007), advection from the continental margins (Lam and Bishop, 2008) and atmospheric deposition with aeolian dust deposition commonly assumed to dominate external iron supply to the open ocean (Jickells et al., 2005). In the NE Pacific Ocean, the supply of iron from dust sources occurs episod- ically (e.g. Bishop et al., 2002; Boyd et al., 1998) dependent on dust storm frequency and atmospheric circulation. According to Boyd et al. (1998), the majority of elevated marine primary productivity events in the open NE Pacific occur during late spring and summer, but the probability of dust transport from Asia is low in late spring and at a minimum during summer. In contrast, the probability of transport from Alaska (including Aleutian Islands) is significantly higher during summer and fall months than from Asia, leading Boyd et al. (1998) to conclude that volcanism in Alaska must also be considered as a potential source region of iron.

Recent laboratory experiments suggest that material from volcanic eruptions such as ash may affect the MPP through rapid iron-release on contact with seawater (Duggen et al., 2007; Jones and Gislason, 2008; Olgun et al., 2010). Direct evidence, however, that volcanic ash can cause natural ironfertilisation and phytoplankton increase has so far been lacking. Here we present first evidence for a large-scale phytoplankton bloom in the iron-limited oceanic region of the NE Pacific. The bloom detected by satellite observations occurs shortly after volcanic ash fall from the eruption of Kasatochi volcano (Aleutian Islands) in August 2008. Iron supply to such an iron-limited region increases chlorophyll- $a(\mathrm{Chl}-a)$ used as proxy for surface ocean biomass - considerably and also affects the climate relevant ocean-atmosphere exchange of chemical trace species (O'Dowd et al, 2004; Turner et al., 2004), e.g. carbon dioxide, organic carbon aerosols and dimethyl sulfide forming sulphate aerosols. These marine aerosols act as efficient cloud condensation nuclei and modify the Earth's radiative budget via the indirect aerosol effect (Lohmann and Feichter, 2005) whereas a drawdown of atmospheric $\mathrm{CO}_{2}$ due to ocean fertilisation (Sarmiento, 1991; Watson, 1997) can have important implications for the global $\mathrm{CO}_{2}$ budget directly affecting the Earth's radiative budget.

Correspondence to: B. Langmann

(baerbel.langmann@zmaw.de)

Published by Copernicus Publications on behalf of the European Geosciences Union. 


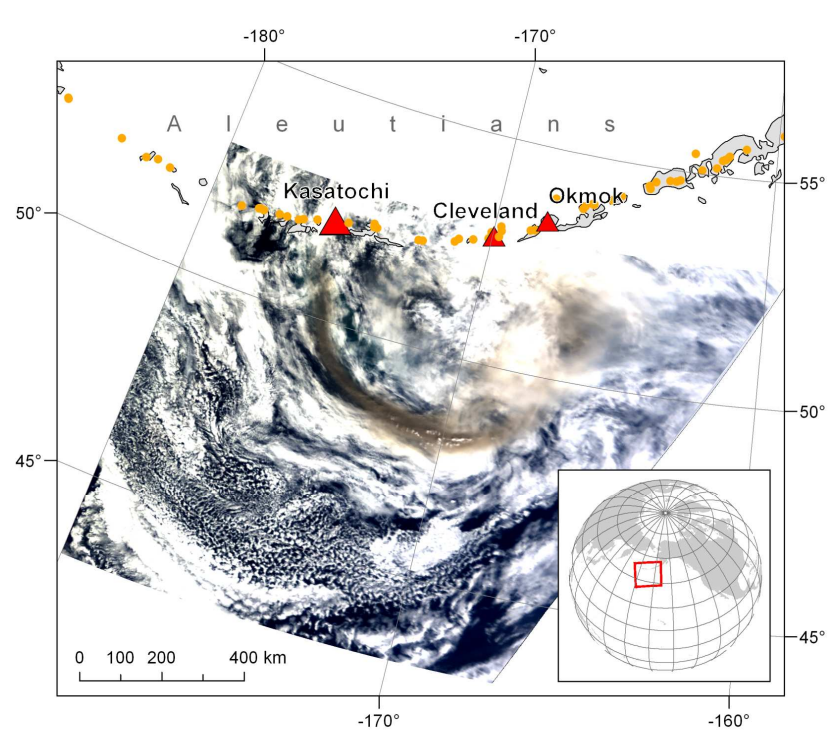

Fig. 1. Aleutian and Alaska volcanoes (orange circles) with Kasatochi, Cleveland and Okmok indicated as red triangles. The ash cloud released from Kasatochi volcano on 8 August is visible in brownish colours in the MODIS satellite image showing the visible wavelength range.

\section{Kasatochi eruption}

During summer 2008, explosive eruptions of three remote Aleutian island arc volcanoes (Fig. 1) occurred. The first eruption took place on 12 July at Okmok volcano, the second and smallest one on 21 July at Cleveland volcano. Larsen et al. (2009) reported an erupted magma volume of $0.081 \mathrm{~km}^{3}$ during the five week eruption period of Okmok volcano with an initial column height of $16 \mathrm{~km}$, which fluctuated in the following weeks between about 2 and $12 \mathrm{~km}$. The largest explosive event of this summer occurred at Kasatochi volcano $\left(52.17^{\circ} \mathrm{N}, 175.51^{\circ} \mathrm{W}\right)$ on 7 and 8 August with three major eruptions that rose to altitudes of about $15 \mathrm{~km}$. The last explosive event on 8 August lasted for about $17 \mathrm{~h}$ (Waythomas et al., 2008a). The ash plume formed a counter-clockwise spiral at altitudes between $9 \mathrm{~km}$ and $14 \mathrm{~km}$ (Fig. 1) and spread further eastward across the NE Pacific (Fig. 2) (http: //www.avo.alaska.edu/activity/Kasatochi.php). It has been estimated that the Kasatochi eruption cloud contained about 1.5 million tons of $\mathrm{SO}_{2}$ (one order of magnitude greater than Okmok), and is one of the largest volcanic $\mathrm{SO}_{2}$ clouds since the eruption of Mt. Pinatubo on the Philippines and Mt. Hudson in Chile in 1991 (http://earthobservatory.nasa.gov/IOTD/ view.php?id=8998). Satellites observations by GOME-2 and OMI reveal large-scale transport of $\mathrm{SO}_{2}$ across the northern latitudes during August 2008. As the major amount of volcanic ash settles within a few days out of the atmosphere (e.g. Rose and Durant, 2009), Fig. 2 indicates that most of the volcanic ash released from Kasatochi settled into the NE Pacific ocean.

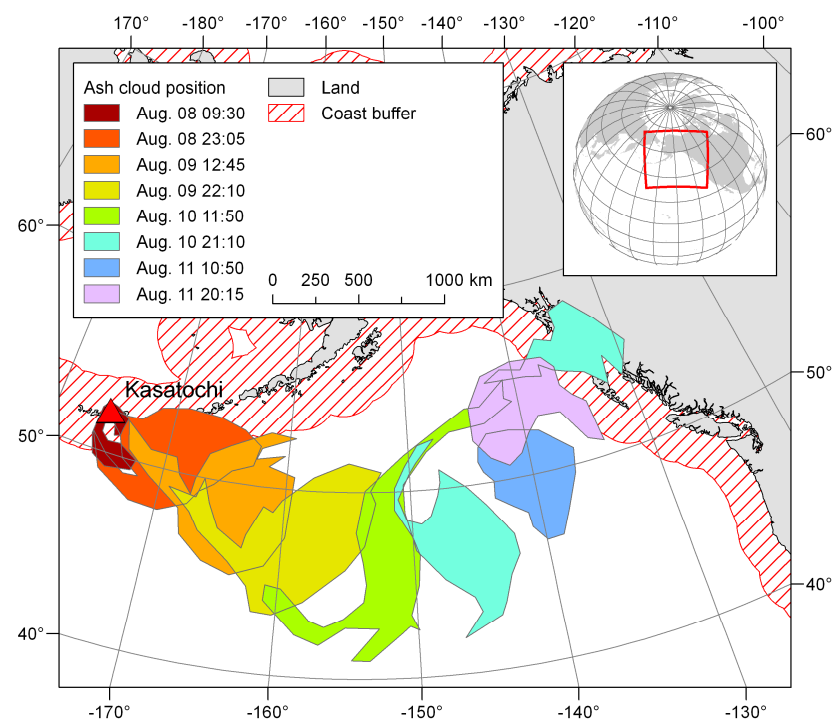

Fig. 2. Atmospheric dispersion of the Kasatochi ash cloud from 8 August to 11 August 2008 based on MODIS level 1b data at 11 and $12 \mu \mathrm{m}$ using BTD.

\section{Chlorophyll-a}

\subsection{Available data}

Remote sensing of ocean colour, detecting surface ocean Chl- $a$ content started in 1978 as the Coastal Zone Color Scanner (CZCS) aboard the Nimbus 7 satellite was launched. Ocean colour is related mostly to the presence of phytoplankton and water clarity, thus remote sensing of ocean colour is a valuable tool to estimate the state of the surface ocean ecosystems. CZCS was operated from 1978 to 1986. Ocean Color and Temperature Scanner (OCTS), its successor, was launched aboard ADEOS satellite in 1996 and ceased operation shortly after because of a malfunction in 1997. In the same year, Sea-viewing Wide Field-of-view Sensor (SeaWiFS) aboard GeoEye's OrbView-2 (AKA SeaStar) satellite was launched. The sensor is still operational and has provided a huge ocean colour data archive. The second operational sensor is Moderate-resolution Imaging Spectroradiometer (MODIS) aboard Terra (launched in 1999) and Aqua satellite (launched in 2002). The advantage of MODIS (in comparison to SeaWiFS) in ocean colour monitoring is the greater number of channels (even in the thermal infrared that enables the retrieval of sea surface temperature - SST). MODIS and SeaWiFS have a spatial resolution of approximately $1 \mathrm{~km}$. MEdium Resolution Imaging Spectrometer (MERIS) aboard Envisat satellite (launched in 2002) is also devoted to ocean colour monitoring. It has a longer revisit time (3 days) than MODIS and SeaWiFS (approximately 1 day) but provides better spatial resolution $(300 \mathrm{~m})$ appropriate for regional studies. 
We use atmospherically corrected MODIS Aqua Level 3 Chl- $a$ data (monthly mapped 9-km) processed by Ocean Color Web (http://oceancolor.gsfc.nasa.gov/) to show first evidence for the build-up of Chlo- $a$ induced by fertilisation from ash released from Kasatochi. As volcanic ash and $\mathrm{SO}_{2}$ atmospheric burden over the NE Pacific Ocean was enhanced only for about four days directly after the eruption of Kasatochi and prior to the phytoplankton bloom, an influence on the atmospheric radiative transfer on Chl- $a$ detection is negligible. A misinterpretation of Chl- $a$ concentration by ash in the surface ocean can also be excluded as volcanic ash particles have residence times in the ocean mixed layer ranging from a few minutes up to 2 days dependent as particle size (Duggen et al., 2007). MODIS Terra data are also available but as already stated in previous studies (Fleming and Korb, 2004; Barbini et al., 2005) they sometimes significantly differ from MODIS Aqua and SeaWiFS data. The algorithm for Chl- $a$ retrieval was developed for SeaWiFS and should be the first choice in such a study but the sensor did not function in July 2008. Therefore, MODIS Aqua data are the optimal choice because the current study aims to show the build-up of Chl- $a$ induced by fertilisation from ash released from Kasatochi using a time series of ocean colour data, which would be impossible in the case of SeaWiFS because of the mentioned data gap.

\subsection{Data analysis}

In the open NE Pacific, low seasonality of MPP occurs with usually only slight enhancement during summer, whereas the coastal areas display phytoplankton blooms during spring and late summer (Boyd and Harrison, 1999). During August to October 2008, however, MODIS Aqua Chlo- $a$ data reveal a considerable increase in the NE Pacific following the Kasatochi eruption. Figure 3 illustrates the difference of the monthly mean Chl- $a$ from May to October 2008 and the average of the monthly mean values of previous years, from 2002 to 2007 for the specific month. A considerable increase of Chl- $a$ is visible over the open NE Pacific in August 2008 over $68 \%$ of the area from $40-65^{\circ} \mathrm{N}$ and 180 $120^{\circ} \mathrm{W}$, still present in October 2008 though with decreasing intensity. At these pixels, Chl- $a$ is doubled (average increase from $0.5 \mathrm{mg} \mathrm{m}^{-3}$ to $1.0 \mathrm{mg} \mathrm{m}^{-3}$ ). When comparing with maximum Chl- $a$ that has been reached in the years 2002 to 2007 , the number of pixels with increased concentration during August 2008 is reduced to 40\%, but a strong increase remains located over the open NE Pacific (average increase from $0.7 \mathrm{mg} \mathrm{m}^{-3}$ to $1.1 \mathrm{mg} \mathrm{m}^{-3}$ ). Less cloud-contaminated pixels appear in August 2008 compared to August 2006 and 2007, however, August 2004 and 2005 show as well comparable few cloud-contaminated pixels in large parts of the NE Pacific Ocean, but no enhanced Chl $a$ concentration. This behaviour shows that the preconditions for Chl- $a$ production in the surface ocean are not restricted to irradiation alone, but that the availability of nutrients is the limiting factor. The
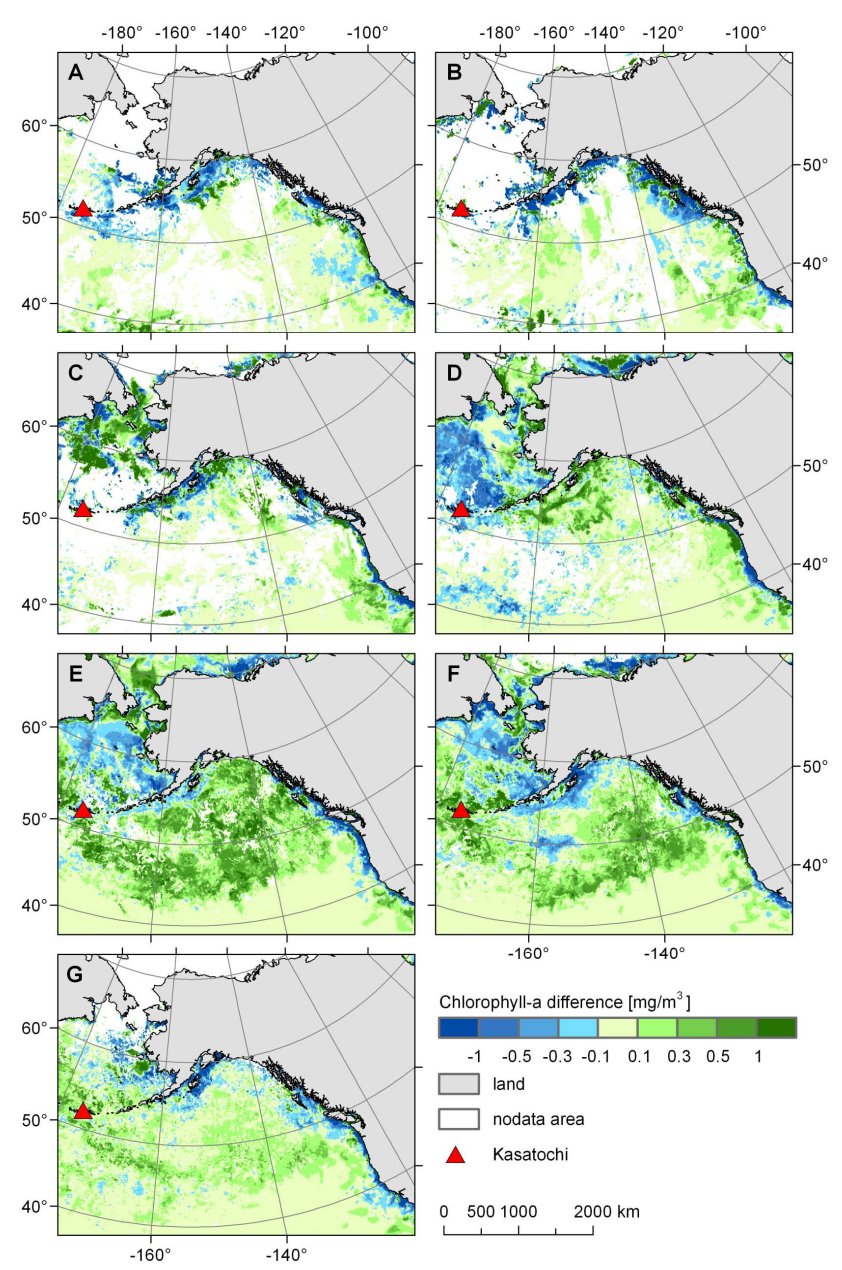

Fig. 3. MODIS Aqua chlorophyll- $a\left[\mathrm{mg} / \mathrm{m}^{3}\right]$ : monthly mean 2008 minus average monthly mean 2002-2007. (A) April, (B) May, (C) June, (D) July, (E) August, (F) September, (G) October.

analysis also showed a considerable increase of Chl- $a$ in August 2008 in comparison to July 2008. In previous years, such an increase from July to August has not been observed (Fig. 4), therefore strongly suggesting a connection to the ash fall of the Kasatochi eruption.

For further analysis, MODIS Aqua 8-day composites of Chl- $a$ for 2008 and averaged data from 2002 to 2007 are illustrated in Fig. 5 as a function of time along the N-S transect from $40^{\circ} \mathrm{N}$ to $60^{\circ} \mathrm{N}$ for the longitudes $165^{\circ} \mathrm{W}, 155^{\circ} \mathrm{W}$, $145^{\circ} \mathrm{W}$ and $135^{\circ} \mathrm{W}$ (see Fig. 6). A $200 \mathrm{~km}$ zone along the coast is removed from the analysis to eliminate coastal nonHNLC regions (Boyd and Harrison, 1999). In 2008, a major anomaly is visible between $45^{\circ} \mathrm{N}$ and $55^{\circ} \mathrm{N}$ starting on julian day 225 corresponding to the period 12-19 August 2008, shortly after the beginning of the eruption of Kasatochi volcano on 7 August. These plots are compared to the mean values for the period 2002-2007 at the same transects (Fig. 5 right) but no significant increase is seen after julian day 225 . 

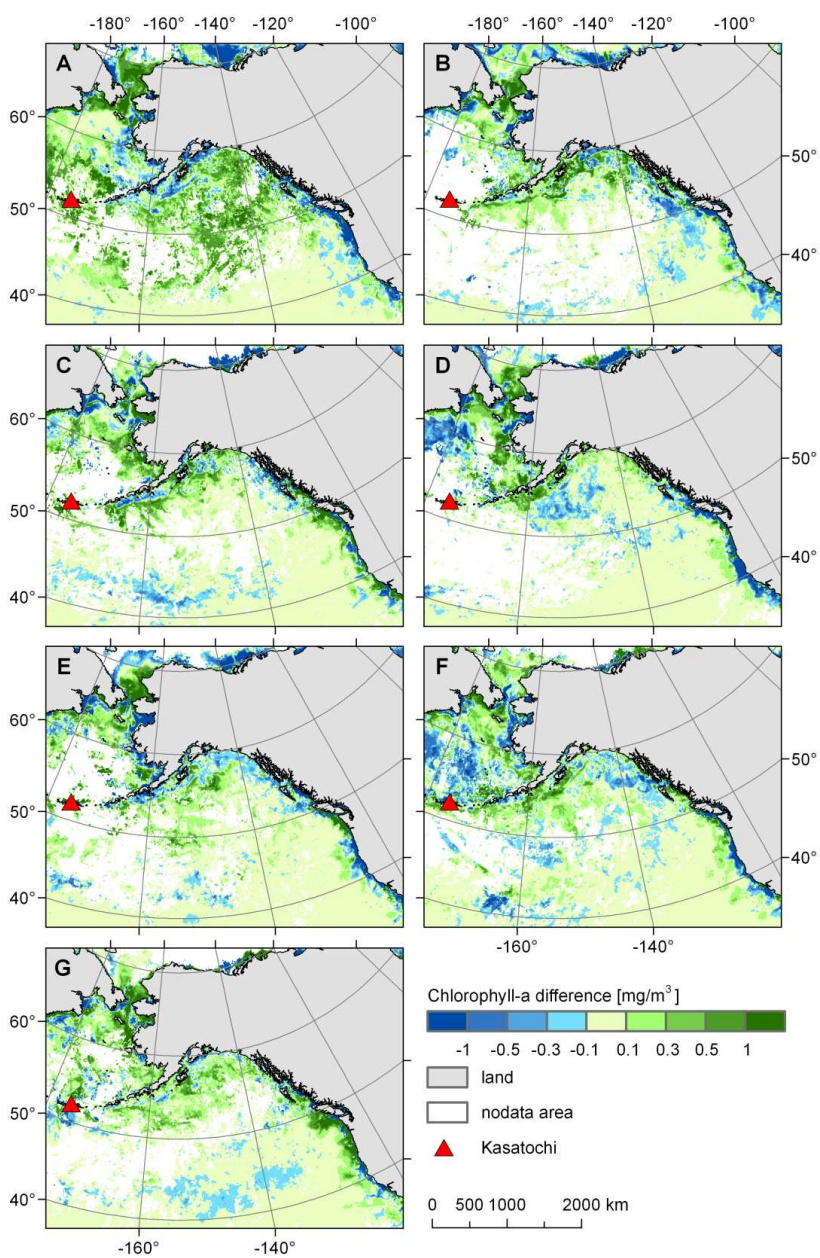

Chlorophyll-a difference $\left[\mathrm{mg} / \mathrm{m}^{3}\right]$

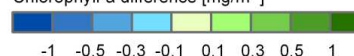

$\begin{array}{rr}-1 & -0.5 \\ \square & \text { land }\end{array}$

$\square$ nodata area

- Kasatoch

O $5001000 \quad 2000 \mathrm{~km}$
Fig. 4. MODIS Aqua chlorophyll- $a\left[\mathrm{mg} / \mathrm{m}^{3}\right]$ : August $200 \mathrm{X}$ minus July 200X. (A) 2008, (B) 2007, (C) 2006, (D) 2005, (E) 2004, (F) 2003, (G) 2002.

These comparisons further emphasise the fertilisation of the NE Pacific by volcanic ash from Kasatochi as to our knowledge there was no other trigger within the 8-days period. Concerning the time lag between fertilisation and bloom, we refer to laboratory experiments by Duggen et al. (2007). Analysis of ash samples from different volcanoes reveal that they exhibit remarkably similar mobilisation patterns of iron in seawater with the highest mobilisation rates within the initial 5-15 min. The laboratory experiments of Duggen et al. (2007) also showed a strong increase of Chl- $a$ starting six days after contact with volcanic ash. From artificial iron fertilisation experiments it is also well know, that Chl- $a$ production responds rapidly to iron supply, after 3 to 5 days (e.g. Martin et al., 1989; Boyd et al, 2004).

Notably, the phytoplankton bloom was also recorded at the ocean station Papa $\left(50^{\circ} \mathrm{N}, 145^{\circ} \mathrm{W}\right)$ which measured a decreased seawater $\mathrm{CO}_{2}$ partial pressure of $30-40 \mathrm{ppm}$ beginning 14 August 2008 (http://www.pmel.noaa.gov/co2/

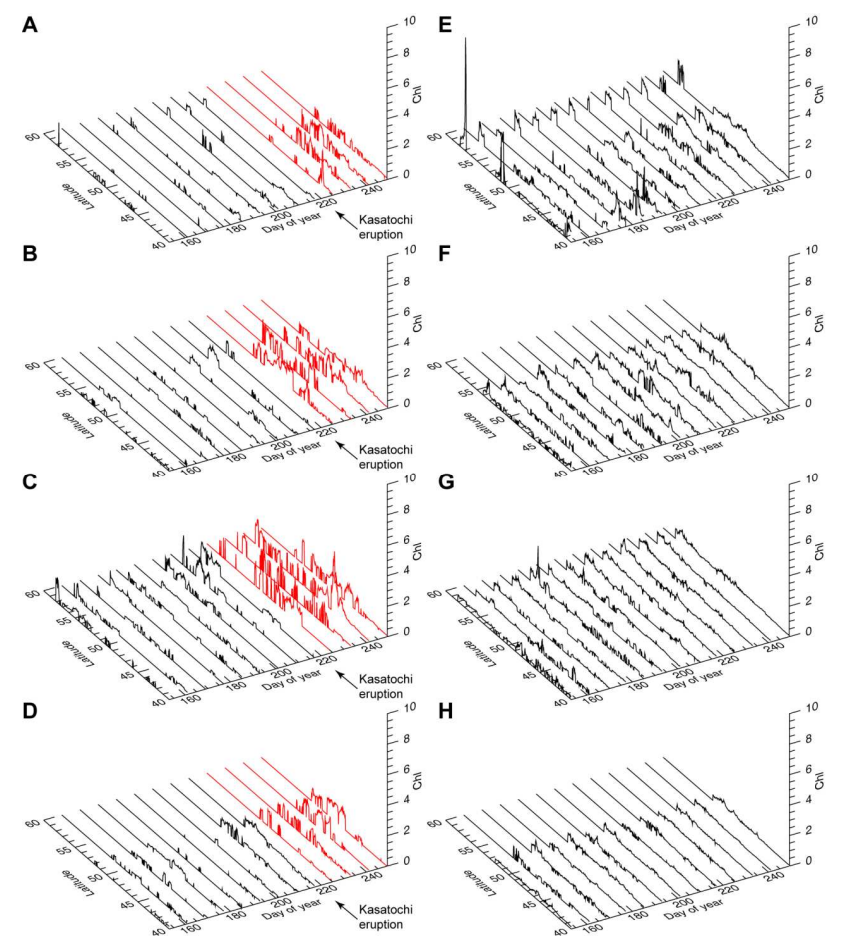

Fig. 5. MODIS Aqua 8-day composites of Chl- $a$ along N-S transects at $175^{\circ} \mathrm{W}(\mathbf{A}$ and $\mathbf{E}), 165^{\circ} \mathrm{W}(\mathbf{B}$ and $\mathbf{F}), 155^{\circ} \mathrm{W}(\mathbf{C}$ and $\mathbf{G})$ and $145^{\circ} \mathrm{W}$ (D and $\mathbf{H}$ ) from $60^{\circ} \mathrm{N}$ to $40^{\circ} \mathrm{N}$ for 2008 (left column: A, B , C , D) and the mean values from 2002 to 2007 (right column: E, F, G, H).

moorings/papa/data_145w_all.htm). This drop in $p \mathrm{CO}_{2}$ has been confirmed by independent measurements from ship cruises (Hamme et al., 2010).

\section{Kasatochi ash flux}

A critical variable to be known in order to firmly establish a link between the volcanic ash and the phytoplankton bloom observed in late summer 2008 is the total mass of ash released by Kasatochi volcano. There are several ways to determine the deposited volcanic ash fall volume and mass (Fierstein and Nathenson, 1992). However, these methods only work if ash is deposited on land. As the island of Kasatochi is only about $7 \mathrm{~km}^{2}$ in size (nearly round shaped with about $3 \mathrm{~km}$ in diameter), almost all volcanic ash was deposited into the NE Pacific making an estimate of the erupted volume using classic methods through mapping the thickness of deposits impossible. A way around this obstacle is presented below: a backward estimate (Sect. 4.2) by calculating the amount of volcanic ash that would have been necessary to generate the observed phytoplankton increase, where first the area affected by ash deposition needs to be determined (Sect. 4.1). Additionally, a 1-d eruption column model is applied to examine if the modelled eruption column height, 
which is strongly dependent on the erupted amount of ash, fits with observation data (Sect. 4.3).

\subsection{Ash deposition area}

MODIS level $1 \mathrm{~b}$ images are used to track the evolution of the Kasatochi ash cloud (Fig. 2) and estimate the area where volcanic ash deposition and the phytoplankton bloom occurred. It is difficult to use a universal detection algorithm for volcanic ash in the atmosphere because the particle radius in the cloud usually varies from 1 to $15 \mu \mathrm{m}$ and the chemical properties vary from one volcano to another (Simpson et al., 2000). Brightness temperature difference (BTD) is often successfully used for ash detection. It is based on the assumption that the differences between measurements at $11 \mu \mathrm{m}$ and $12 \mu \mathrm{m}$ wavelength are positive for meteorological clouds containing water or ice. If the differences are negative, there is a high probability that the cloud contains ash. In the visible channels, ash is detected from the images retrieved shortly after the eruption ended (Fig. 1). The ash cloud is further tracked using BTD from channels 31 and 32 $(11 \mu \mathrm{m}$ and $12 \mu \mathrm{m})$ until it reaches the continent. MODIS images are geo-referenced and ash clouds are vectorised in order to estimate the area of the ash dispersion. Merely the open ocean is of interest to this study (because phytoplankton growth is not iron-limited in turbid waters, Boyd and Harrison, 1999), thus a $200 \mathrm{~km}$ buffer around the coastline is not considered in the area estimate (Fig. 6). Furthermore, only the areas, where the value of Chl- $a$ from July to August raised at least by $25 \%$ are assumed to represent a phytoplankton bloom (Bishop et al., 2002). Missing Chl$a$ data points due to cloud coverage are filled by interpolation, finally resulting in an area estimate of $1.5 \times 10^{6} \mathrm{~km}^{2}$. A second area estimate of $2 \times 10^{6} \mathrm{~km}^{2}$ is based on the information of ash coverage provided by the Volcanic Ash Advisory Centre (VAAC, http://www.ssd.noaa.gov/VAAC/ ARCH08/archive.html\#KASA) (Fig. 6) and shows a further north-south extension on the last date compared to Fig. 2. As VAAC has to assure aircraft security, a huge ash cloud dimension is assumed for safety reason, but the major ash distribution area is expected to be restricted between $40-55^{\circ} \mathrm{N}$ and $175-140^{\circ} \mathrm{W}$.

\subsection{Backward estimate}

In laboratory experiments, unhydrated (pristine) volcanic ash samples release between 35-320 nmol Fe per gram ash within the initial 60 min of contact with ocean water (Duggen et al., 2007; Olgun et al., 2010), revealing the potential of volcanic ash to swiftly iron-fertilise the euphotic zone of the surface ocean. However, many questions related to the amount of bio-available iron attached to aerosols in general and volcanic ash in particular are still unanswered as standardised and systematic measurements of a wide range of chemical (e.g. acid and alkali concentration, mineralogy, ph)

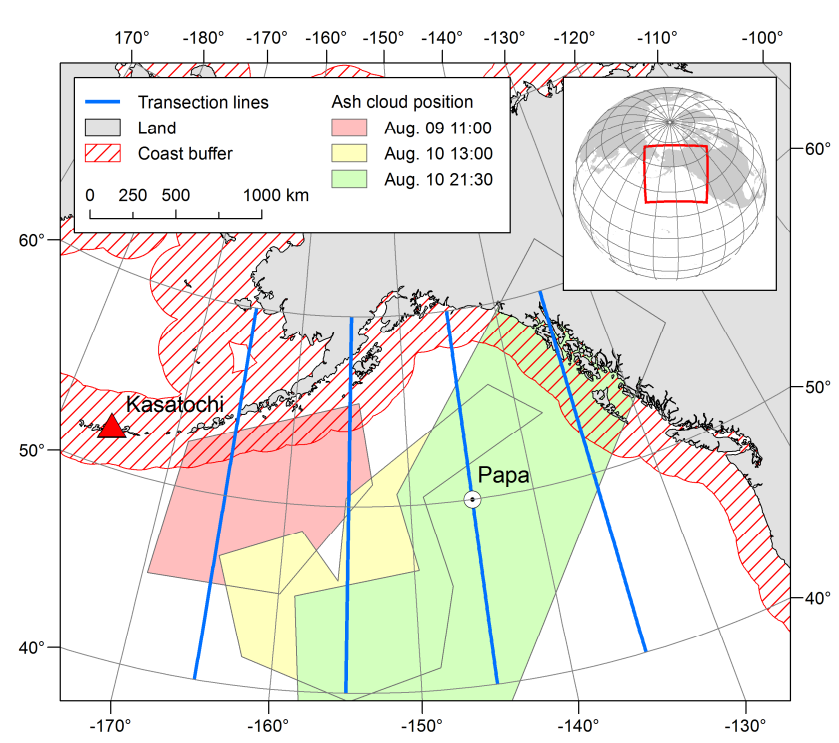

Fig. 6. To eliminate the signal from nutrient supply in coastal areas, a $200 \mathrm{~km}$ buffer along the coast (striped red) is removed from the analysis. The blue lines mark the positions of the N-S transects for the analysis of the MODIS Aqua 8-day composites of Chl- $a$. The coloured polygons illustrate the dimension and the changing position of the volcanic ash plume as provided by VAAC.

and physical (e.g. particle mass and size, temperature) variables are not yet available (e.g. Baker and Croot, 2008). Results from mesoscale iron enrichment experiments show that an increase of surface ocean iron concentrations by $2-3 \mathrm{nM}$ is sufficient for large diatoms to grow rapidly in iron-limited regions (Wells, 2003) such as the NE Pacific (usually with $\mathrm{Fe}<0.1 \mathrm{nM}$ ). Assuming an ocean mixed layer depth of $30 \mathrm{~m}$ (Whitney and Freeland, 1999; http://www.pac.dfo-mpo.gc. ca/science/oceans/Argo/Argo-melange-mixed-eng.htm) and that an enhancement of $2 \mathrm{nM} \mathrm{Fe}$ is needed to produce the observed phytoplankton bloom, a total amount of 0.9$1.2 \times 10^{17} \mathrm{nmol} \mathrm{Fe}$ is required for the fertilised area of 1.5$2 \times 10^{6} \mathrm{~km}^{2}$. Subduction zone volcanic ash is assumed to releases about $200 \mathrm{nmol}$ Fe per gram ash (Olgun et al., 2010) suggesting that Kasatochi volcano, situated in the Aleutian subduction zone, deposited a total mass of ash of around 4.5$6 \times 10^{11} \mathrm{~kg}$ in the NE Pacific. The mass corresponds to a volume of $0.23-0.30 \mathrm{~km}^{3}$ (assuming a density of $2000 \mathrm{~kg} \mathrm{~m}^{-3}$, Folch et al., 2008) which is a reasonable estimate in comparison with historical volcanic eruptions (Schmincke, 2004).

Three-dimensional atmospheric dispersion and deposition modelling of $6 \times 10^{11} \mathrm{~kg}$ of ash released from Kasatochi volcano (Langmann et al., 2010) shows that the highest ash fall occurs of course close to the volcano, but also that fallout into the NE Pacific Ocean makes up $92 \%$ of the total ash mass removed from the atmosphere. With the assumption that bio-available iron is released from iron salts coating the surface of ash particles, we can conclude that finer ash particles carry more iron per mass unit than coarser ones due to 


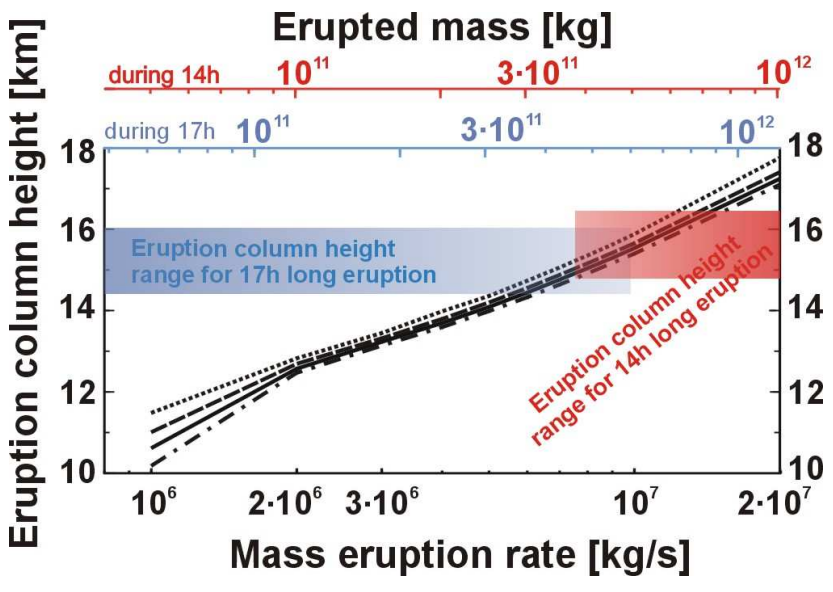

Fig. 7. Model calculation showing the rise height of the eruption cloud during a volcanic eruption as a function of the mass eruption rate. The solid line is for a gas content of $3 \mathrm{wt} \%$, an initial velocity of $300 \mathrm{~m} \mathrm{~s}^{-1}$. The dotted line is for $3 \mathrm{wt} \%$ and $100 \mathrm{~m} \mathrm{~s}^{-1}$ initial velocity, the dash dotted line is for $2 \mathrm{wt} \%$ and $300 \mathrm{~m} \mathrm{~s}^{-1}$, and finally the dashed line is for $4 \mathrm{wt} \%$ and $300 \mathrm{~m} \mathrm{~s}^{-1}$. The top two axes show the erupted mass in case the eruption lasted for 14 or $17 \mathrm{~h}$.

the larger surface area of the finer particles. After a volcanic eruption, ash particle diameter and mass principally decrease with time and distance from the volcano, so that close to the volcano generally bigger particles with less iron sink relatively faster through the ocean mixed layer than further away from the volcano, where smaller ash particles with more iron per unit mass sink slower. These processes can compensate each other to a certain extent and can lead thereby to a more uniform distribution of iron in the surface ocean than expected. Thus the use of the simplified assumption of an evenly spread ash fall area to estimate the erupted ash mass is assumed to represent an acceptable simplification.

\subsection{1-d eruption column model estimate}

Another estimate of the erupted mass is determined by applying a simple 1-D eruption column model based on the entrainment measured in turbulent jets (Morton et al., 1956). This approach has been successfully applied to volcanic eruptions (Woods, 1988; Glaze and Baloga, 1996; Hort and Gardner, 2000). Those models are based on a thermal and mass flux at the vent entering into the atmosphere. Dilution of the erupted hot mixture of gases and ash through entrainment of air reduces the overall density of the erupted mixture. Under favourable conditions this leads to a buoyant mixture of volcanic gases, air and ash rising in the atmosphere until the level of neutral buoyancy is reached. Under unfavourable conditions (e.g. Woods, 1988), however, the eruption column may collapse leading to e.g. pyroclastic flows. The models robustly predict the rise height of volcanic eruption columns which has been verified by comparing observed eruption column heights with the model results. Recently, a public do- main code (Mastin, 2007) was provided to carry out such calculations, which is used in this study.

Main input values to the model are mass flux (through entering a vent size, an initial velocity, and the weight percentage (wt \%) of volcanic gas), atmospheric conditions and eruption temperature. Because the eruption column rise height is quite independent of the eruption temperature, $900^{\circ} \mathrm{C}$ are assumed as eruption temperature, a typical value for arc volcanoes (Pichler and Pichler, 2007). The initial gas content is varied between 2 and $4 \mathrm{wt} \%$, the former being a lower estimate, the upper one being more on the upper end based on typical amounts of water contents of magmas in arc settings released during eruptions. Atmospheric conditions from radiosonde measurements at station PASY (http://weather.uwyo.edu/upperair/sounding.html) on the island of Shemya $\left(52.7^{\circ} \mathrm{N}, 174.1^{\circ} \mathrm{W}\right)$ on 8 August 2008 at 12:00 UTC are used.

We carried out 4 sets of model calculations. In each set of calculations the eruption velocity and the gas content were fixed along with the other values explained above. Through varying the vent size, the mass flux was varied in order to cover a range of mass fluxes from $10^{6}$ to $2 \times 10^{7} \mathrm{~kg} \mathrm{~s}^{-1}$. The results of the model calculations are shown in Fig. 7. Clearly, the parameter controlling the rise height of the eruption column is the mass flux. In three of the four calculations the initial eruption velocity was fixed at $300 \mathrm{~m} \mathrm{~s}^{-1}$ (solid (3 wt\% gas), dashed ( $2 \mathrm{wt} \%$ gas), and dash-dotted line (4 wt $\%$ gas)) and one calculation was carried out with an initial eruption velocity of $100 \mathrm{~m} \mathrm{~s}^{-1}$ ( $3 \mathrm{wt} \%$ gas, dotted line). A velocity of $300 \mathrm{~m} \mathrm{~s}^{-1}$ at the vent implies supersonic speeds of the erupted material, in case of $100 \mathrm{~m} \mathrm{~s}^{-1}$ eruption speeds are subsonic. The speed of sound of the erupted mixture varies between 118 ( $2 \mathrm{wt} \%$ gas) and $166 \mathrm{~m} \mathrm{~s}^{-1}$ (4 wt $\%$ gas).

From satellite observations it is known that the duration of the continuous eruption of Kasatochi volcano was between 14 and 17 ho (Waythomas et al., 2008a, b). This neglects the two initial explosions before the main event that did not produce much ash. The reported eruption column height (Waythomas et al., 2008a, b) is around $15 \mathrm{~km}$. The top two $\mathrm{x}$-axes in Fig. 7 show a conversion of the mass flux at the vent into a total erupted mass for the two durations (14 and $17 \mathrm{~h}$ ). As detailed in Sect. 4.2, the approximate ash mass needed to explain the phytoplankton bloom is in the order of $5 \times 10^{11} \mathrm{~kg}$. In Fig. 7 we marked the eruption column height range for a total erupted mass between 4 and $6 \times 10^{11} \mathrm{~kg}$. They result in minimum and maximum eruption column heights necessary to produce the proper amount of ash. In case of a $17 \mathrm{~h}$ duration (blue area), an eruption column height between 14 and $16 \mathrm{~km}$ is required, in the case of a $14 \mathrm{~h}$ duration (red area) the height varies between 15 and $16.5 \mathrm{~km}$. Importantly, those height are in the range of the actual observed eruption column height. This means that the eruption produced enough ash needed to explain the phytoplankton growth in the NE Pacific. 
Guffanti et al. (2008) reported an estimate of the ash volume of the Kasatochi eruption ranging from 0.1 and $0.25 \mathrm{~km}^{3}$ similar to the above estimate of $0.23-0.3 \mathrm{~km}^{3}$. The minimum estimate of an ash volume of $0.1 \mathrm{~km}^{3}$ of Guffanti et al. (2008) would result in plume heights of 13-14 km (Fig. 7), and can therefore be considered to be at the lower range of the erupted mass of ash.

\section{Discussion}

In summary, the data and analysis presented above argue in favour of a causal connection between the Kasatochi eruption and the large-scale phytoplankton bloom in the NE Pacific in late summer 2008. In addition, oceanic and atmospheric conditions in the NE Pacific area provide valuable assistance for the iron-fertilisation by volcanic ash released from Kasatochi volcano. First, the two current systems dominating the circulation of the NE Pacific, the Alaska Coastal Current and the North Pacific Current (Stabeno et al., 2004), offer favourable conditions to geographically trap the iron released from volcanic ash within the region. Second, the mixed layer depth is at a minimum of about $20-40 \mathrm{~m}$ in August/September (Whitney and Freeland, 1999), strongly restricting the fertilisable surface ocean water volume. Third, the stable surface ocean water mass stratification facilitates the recycling of nutrients in the mixed layer so that the phytoplankton bloom could last for several weeks. Fourth, during August enough sunlight is available to support phytoplankton production.

Okmok released about a factor of three less ash than Kasatochi (Larsen et al., 2009) if we consider $0.25 \mathrm{~km}^{3}$ as a reasonable estimate for the Kasaochi ash volume. Due to the longer lasting eruption of Okmok and smaller eruption column heights after the initial eruption, one can assume a considerable amount of ash to be deposited close to Okmok, strengthened by the reported formation of water- and ice-ash aggregates that settle quickly within a few hundred kilometres. Following this assumption, a fertilisation of the surface NE Pacific by volcanic ash from Okmok volcano must have been significantly smaller than that following the eruption of Kasatochi volcano.

East of Kamchatka, in an oceanographically complex area, another phytoplankton bloom occurred during summer 2008. The Aleutian Islands meet the Kamchatka peninsula in this region, creating complex bathymetry (islands, seamounts and ocean trenches). From our analysis we do not see a connection between the ash released from Kasatochi volcano and the phytoplankton bloom east of Kamchatka. We conclude that other reasons like coastal effects must have played a role.

For the sake of completeness it should be mentioned that a shift of the Pacific Decadal Oscillation (PDO) to its cool phase has been going on since early 2008 following the 2007 La Niña (http://jisao.washington.edu/pdo) with cooler sea surface temperatures (SST) than in previous years. Similar shifts of the PDO (Peterson and Schwing, 2003) were observed in 1998 and 1947. However, there is no correlation of the phytoplankton bloom in August 2008 with a SST decrease thus excluding nutrient supply through upwelling. In addition, in 1998 SeaWifs Chl- $a$ data did not show an increase from July to August 1998 over the NE Pacific, thereby emphasising the extraordinary conditions during August 2008.

\section{Conclusions and outlook}

The data presented in this study strongly support the ironfertilisation effect of the surface ocean by volcanic ash. So far, studies of volcanic forcing on climate focussed on the radiative effect of sulphate aerosols formed from volcanic $\mathrm{SO}_{2}$ in the atmosphere. The Kasatochi example demonstrates surface ocean iron-fertilisation and phytoplankton increase by volcanic ash although the volcanic ash flux from Kasatochi was small in comparison to major historical volcanic eruptions (Schmincke, 2004).

Major volcanic eruptions may also have a considerable short-term influence on the Earth's radiative balance by affecting the atmospheric $\mathrm{CO}_{2}$ budget via the biological $\mathrm{CO}_{2}$ pump and cloud properties via the indirect aerosol effect. However, large volcanic eruptions are rare and occur only sporadic and episodic and iron-fertilisation is restricted to $\mathrm{HNCL}$ regions. The $\mathrm{C} / \mathrm{Fe}$ ratio at which phytoplankton from $\mathrm{Fe}$-limited oceanic areas incorporate $\mathrm{C}$ and iron in their tissue (about $1 \cdot 10^{5}$; Watson, 1997) allows an estimate of the amount of $\mathrm{CO}_{2}$ transferred into biomass as a consequence of the 2008 Kasatochi iron-fertilization event. If all of the $1.0 \cdot 10^{8} \mathrm{~mol}$ of iron (as inferred above) were utilised to built up phytoplankton biomass, then about $1.2 \cdot 10^{14} \mathrm{~g}$ of carbon could have been removed from the atmosphere. The amount is about an order of magnitude less than observed for the post-Pinatubo $\mathrm{CO}_{2}$-drawdown $\left(1.6 \cdot 10^{15} \mathrm{~g}\right.$ of carbon if applied to the northern hemisphere; Sarmiento, 1993), but it is unclear if terrestrial or oceanic biosphere processes (Sarmiento, 1993) or processes independent of Pinatubo lead to the observed atmospheric $\mathrm{CO}_{2}$ reduction. The 1991 Pinatubo eruption released about $1.3-1.8 \cdot 10^{16} \mathrm{~g}$ of ash and thus about a factor of 30 more material than the 2008 Kasatochi eruption, of which, however, only a minor part (few percent) could have reached the iron-limited Southern Ocean for fertilisation (Watson, 1997; Sarmiento, 1993). Interestingly, the direct deposition of volcanic ash from the Mt. Hudson eruption in Chile in 1991 into the iron-limited Atlantic sector of the Southern Ocean (Scasso et al., 1994) was not even considered in explaining the observed $\mathrm{CO}_{2}$ drawdown of the 90ies, although the estimated amount of Mt. Hudson ash $\left(6.5 \cdot 10^{15} \mathrm{~g}\right)$ which settled into the Southern Ocean exceeds the contribution from Pinatubo by far.

Another example is the eruption of Huaynaputina volcano in Peru in 1600 (de Silva and Zielinski, 1998). Volcanic ash settled into the tropical Pacific as well as the Southern Ocean, 
two large HNLC areas (Wells et al., 2003). The amount of tephra released by Huaynaputina in 1600 is $19.2 \mathrm{~km}^{3}$ minimum (de Silva and Zielinski, 1998), which is a factor of about 77 in comparison to Kasatochi, resulting in an amount of carbon consumed by phytoplankton of $9.2 \cdot 10^{15} \mathrm{~g} \mathrm{C}$. The iron-fertilisation potential of this event could serve as an explanation for the atmospheric $\mathrm{CO}_{2}$ reduction by about $10 \mathrm{ppm}$ which was measured in Antarctic ice cores after 1600 (Meure et al., 2006), but this mechanism has not been taken into account until now.

Acknowledgements. This work is supported through the Cluster of Excellence "CliSAP" (EXC177), University of Hamburg, funded through the German Science Foundation (DFG) and the research group NOVUM at IFM-GEOMAR. S. D. receives additional support from the German Science Foundation (Grant HO1833/18-1). K. Z. is funded by the Geotechnology project Exupery. This publication is also a contribution to the Collaborative Research Centre 574 "Volatiles and Hazards in Subduction Zones" at University Kiel.

Edited by: C. McNeil

\section{References}

Baker, A. R. and Croot, P. L.: Atmospheric and marine controls on aerosol iron solubility in seawater, Marine Chem., doi:10.1016/j.marchem.2008.09.003, in press, 2008.

Barbini, R., Colao, F., Fantoni, R., et al.: Comparison of SeaWiFS, MODIS-Terra and MODIS-Aqua in the Southern Ocean, Int. J. Remote Sensing, 26, 2471-2478, 2005.

Bishop, J. K. B., Davis, R. E., and Sherman, J. T.: Robotic observations of dust storm enhancement of carbon biomass in the North Pacific, Science, 298, 817-821, 2002.

Boyd, P., Wong, C. S., Merrill, J., Whitney, F., Snow, J., Harrison, P. J., and Gower, J.: Atmospheric iron supply and enhanced vertical carbon flux in the NE subarctic Pacific: Is there a connection?, Global Biogeochem. Cy., 12, 429-441, 1998.

Boyd, P. and Harrison, J. T.: Phytoplankton dynamics in the NE subarctic Pacific, Deep-Sea Res. II, 46, 2405-2432, 1999.

Boyd P., Law, C. S., Wong, C. S., et al.: The decline and fate of an iron-induced subarctic phytoplankton bloom, Nature, 428, 549553, 2004.

Castro, P. and Huber, E. M.: Marine Biology, McGraw-Hill Book Company, 2007.

de Silva, S. L. and Zielinski, G. A.: Global influence of the AD1600 eruption of Huaynaputina, Peru, Nature, 393, 455-458, 1998.

Duggen, S., Croot, P., Schacht, U., and Hoffmann, L.: Subduction zone volcanic ash can fertilize the surface ocean and stimulate phytoplankton growth: Evidence from biogeochemical experiments and satellite data, Geophys. Res. Lett., 34, L01612, doi:10.1029/2006GL027522, 2007.

Fleming, A. H. and Korb, R. E.: A comparison of satellite and cruise chlorophyll-alpha measurements in the Scotia Sea, Antarctica. IEEE Int, Geoscience and Remote Sensing Symposium proceedings, 1-7, 3485, 2004.

Fierstein, J. and Nathenson, M.: Another look at the calculation of fallout tephra volumes, Bull. Volcanol., 54, 156-167, 1992.
Folch, A., Jorba, O., and Viramonte, J.: Volcanic ash forecast application to the May 2008 Chaiten eruption, J. Nat. Hazards Earth Syst. Sci., 8, 927-940, 2008, http://www.nat-hazards-earth-syst-sci.net/8/927/2008/.

Glaze, L. S. and Baloga, S. M.: Sensitivity of buoyant plume heights to ambient atmospheric conditions: Implications for volcanic eruption columns, J. Geophys. Res., 101, 1529-1540, 1996.

Guffanti, M., Schneider, D. J., Ewert, J. W., and Targosz, S.: Impact on aviation operations of volcanic gas and ash clouds from the 2008 eruptions of Okmok and Kasatochi, Alaska, EOS Trans. AGU 89(53), Fall Meet. Suppl. Abstract A53B-0277, 2008.

Hamme, R., Batten, S., Coogan, L., et al.: Natural volcanic iron fertilization of the Subarctic North Pacific, Eos Trans. AGU, 91(26), Ocean Sci. Meet. Suppl., Abstract IT23C-01, 2010.

Hort, M. and Gardner, J.: Constraints on cooling and degassing of pumice during Plinian volcanic eruptions based on model calculations, J. Geophys. Res., 105, 25981-26001, 2000.

Jickells, T. D. , An, Z. S., Andersen, K. K., et al.: Global iron connections between desert dust, ocean biogeochemistry, and climate, Science, 308, 67-71, 2005.

Jones, M. T. and Gislason, S. R.: Rapid releases of metal salts and nutrients following the deposition of volcanic ash into aqueous environments, Geochimica et Cosmochimica Acta, 72, 36613680, 2008.

Lam, P. J. and Bishop, J. K. B.: The continental margin is a key source of iron to the HNLC North Pacific Ocean, Geophys. Res. Lett., 35, L07608, doi:10.1029/2008GL033294, 2008.

Langmann, B., Zakšek, K. and Hort, M.: Atmospheric distribution and removal of volcanic ash after the eruption of Kasatochi volcano: A regional model study, J. Geophys. Res., doi:10.1029/2009JD013298, in press, 2010.

Larsen, J., Neal, C., Webley, P., Freymueller, J., Haney, M., McNutt, S., Schneider, D., Prejean, S., Schaefer, J., and Wessels, R.: Eruption of Alaska volcano breaks historic pattern, EOS, 90, 173-174, 2009.

Lohmann, U. and Feichter, J.: Global indirect aerosol effects: a review, Atmos. Chem. Phys., 5, 715-737, 2005, http://www.atmos-chem-phys.net/5/715/2005/.

Martin, J. H. and Fitzwater, S. E.: Iron deficiency limits phytoplankton growth in the north-east Pacific subarctic, Nature, 331, 341-343, 1988.

Martin J. H., Gordon R. M., Fitzwater S., and Broekenkow W. W.: VERTEX: phytoplankton/iron studies in the Gulf od Alaska, Deep-Sea Res., 36, 649-680, 1989.

Mastin, L. G.: A user-friendly one-dimensional model for wet volcanic plumes, Geochemistry, Geophysics, Geosystems, Technical Brief 8, No. 3, 2007.

Meure, C. M., Etheridge, D., Trudinger, C., et al.: Law Dome $\mathrm{CO}_{2}$, $\mathrm{CH}_{4}$ and $\mathrm{N}_{2} \mathrm{O}$ ice core records extended to 2000 years BP, Geophys. Res. Lett., 33, L14810, doi:10.1029/2006GL026152, 2006.

Morton, B. R., Taylor, G., and Turner, J. S.: Turbulent gravitational convection from maintained and instantaneous sources, Proc. Roy. Soc. Lond. A, 234, 1-23, 1956.

O’Dowd, C. D., Facchini, M. C., Cavalli, F., et al.: Biogenically driven organic contribution to marine aerosol, Nature, 431, 676680, 2004.

Olgun N., Duggen, S., Croot, P., et al.: Surface ocean iron fertilization: The role of subduction zone and hotspot volcanic ash and fluxes into the Pacific Ocean, Glob. Biogeochem. Cy., submitted, 
2010.

Peterson, W. T. and Schwing, F. B.: A new climate regime in northeast pacific ecosystems, Geophys. Res. Lett., 30, 1896, doi:10.1029/2003GL017528, 2003.

Pichler, H. and Pichler, T.: Vulkangebiete der Erde, Elsevier GmbH Spektrum Akademischer Verlag München, 2007.

Rose, W. I. and Durant, A. J.: Fine ash content of explosive eruptions, J. Volc. Geotherm. Res., 186, 32-39, 2009.

Sarmiento, J. L.: Atmospheric $\mathrm{CO}_{2}$ stalled, Nature, 365, 697-698, 1993.

Scasso, R. A., Corbella, H., and Tiberti, P.: Sedimentological analysis of the tephra from the 12-15 August 1991 eruption of Hudson volcano, Bull. Volcanol., 56, 121-132, 1994.

Schmincke, H. U.: Volcanology, Springer Verlag, Berlin Heidelberg, 2004.

Simpson, J. J., Hufford, G., Pieri, D., and Berg, J.: Failures in detecting volcanic ash from satellite-based technique, Remote Sens. Environ., 72, 191-217, 2000.

Stabeno, P. J., Bond, N. A., Hermann, A. J., et al.: Meteorology and oceanography of the Northern Gulf of Alaska, Continental Shelf Research, 24, 859-897, 2004.

Turner, S. M., Harvey, M. J., Law, C. S., Nightingale, P. D., and Liss, P. S.: Iron-induced changes in oceanic sulfur biogeochemistry. Geophys. Res. Lett., 31, L14307, doi:10.1029/2004GL020296, 2004.
Watson, A. J.: Volcanic iron, $\mathrm{CO}_{2}$, ocean productivity and climate, Nature, 385, 587-588, 1997.

Waythomas, C. F., Prejean, S. G., and Schneider, D. J.: Small Volcano, Big Eruption, Scientists Rescued Just in Time, US Department of the Interior, http://www.avo.alaska.edu/activity/ Kasatochi08/Kasatochi2008PLW.php, 2008a.

Waythomas, C. F., Schneider, D. J., and Prejean, S. G.: The 2008 eruption of Kasatochi volcano, Central Aleutian Islands: Reconnaissance observations and preliminary physical volcanology, Eos Trans. AGU 89(53), Fall Meet. Suppl., Abstract A51J-02, 2008 b.

Wells, M. L.: The level of iron enrichment required to initiate diatom blooms in HNLC waters, Marine Chem., 82, 101-114, 2003.

Whitney, F. A. and Freeland, H. J.: Variability in upper-ocean water properties in the NE Pacific Ocean. Deep-Sea Res. II, 46, 23512370, 1999.

Woods, A. W.: The fluid dynamics and thermodynamics of eruption columns, Bull. Volcanol., 50, 169-193, 1988. 